\title{
Synthesis of $\alpha-\mathrm{MnO}_{2}$ Nanomaterial from a Precursor $\gamma-\mathrm{MnO}_{2}$ : Characterization and Comparative Adsorption of $\mathrm{Pb}(\mathrm{II})$ and $\mathrm{Fe}(\mathrm{III})$
}

\author{
Van-Phuc Dinh, ${ }^{1}$ Ngoc-Chung Le, ${ }^{2}$ Thi-Phuong-Tu Nguyen, ${ }^{1}$ and Ngoc-Tuan Nguyen ${ }^{3}$ \\ ${ }^{1}$ Dong Nai University, Tan Hiep Ward, Biên Hòa City, Đônng Nai Province, Vietnam \\ ${ }^{2}$ Dalat University, Dalat City, Lâm Đồng Province, Vietnam \\ ${ }^{3}$ Vietnam Atomic Energy Institute, Hanoi, Vietnam \\ Correspondence should be addressed to Van-Phuc Dinh; dinhvanphuc82@gmail.com
}

Received 27 July 2016; Accepted 8 September 2016

Academic Editor: Frederic Dumur

Copyright (C) 2016 Van-Phuc Dinh et al. This is an open access article distributed under the Creative Commons Attribution License, which permits unrestricted use, distribution, and reproduction in any medium, provided the original work is properly cited.

$\alpha-\mathrm{MnO}_{2}$ nanostructure was successfully synthesized via hydrothermal treatment of a precursor $\gamma-\mathrm{MnO}_{2}$. Structure, morphology, and BET surface area were characterized using X-ray powder diffraction (XRD), Scanning Electron Microscopy (SEM), and Brunauer-Emmett-Teller nitrogen adsorption (BET- $\mathrm{N}_{2}$ adsorption). Thermal analysis result showed that $\alpha-\mathrm{MnO}_{2}$ nanorods were formed from $\gamma-\mathrm{MnO}_{2}$ at $600^{\circ} \mathrm{C}$. In addition, $\mathrm{Pb}$ (II) and $\mathrm{Fe}(\mathrm{III})$ adsorptive properties were investigated in an optimal condition. Results showed that equilibrium adsorption was obtained after 60 minutes for $\mathrm{Pb}(\mathrm{II})$ at $\mathrm{pH}=4.0$ and 80 minutes for $\mathrm{Fe}$ (III) at $\mathrm{pH}=3.5$ with $240 \mathrm{rpm}$ of shaking speed overall. Experimental data was analyzed using three models: Langmuir, Freundlich, and Sips. Adsorption capacities $\left(q_{m}\right)$ from the Langmuir isotherm models are $124.87 \mathrm{mg} / \mathrm{g}$ for $\mathrm{Pb}(\mathrm{II})$ and $30.83 \mathrm{mg} / \mathrm{g}$ for Fe(III). Along with the highest corelation coefficients, it is clear that the adsorption of $\mathrm{Pb}$ (II) and $\mathrm{Fe}$ (III) ions on $\alpha-\mathrm{MnO}_{2}$ surface followed Sips model. Kinetic studies indicated that the uptake of $\mathrm{Pb}(\mathrm{II})$ and $\mathrm{Fe}(\mathrm{III})$ occurred in the pseudo-second-order model with two stages for $\mathrm{Pb}(\mathrm{II})$ and three stages for $\mathrm{Fe}(\mathrm{III})$.

\section{Introduction}

Nowadays, the human health and the environment are in danger owing to the increase in industrial and mining activities [1]. Lead and iron ions seriously affect human life even in trace concentrations. According to the Environmental Quality Act, the limit for lead and iron in water is less than $0.1 \mathrm{mg} / \mathrm{L}$ and $1.0 \mathrm{mg} / \mathrm{L}$. Therefore, there are many physicochemical treatments used to remove them, such as chemical precipitation, adsorption and ionic exchange, membrane technology, and solvent extraction. One of the most efficient and promising methods for treatment of lead and iron ions from an aqueous solution is the adsorption technology because of its high enrichment efficiency and ease of phase separation [2].

Being well known as a low-cost and environmentally friendly material, manganese oxides have been studied and applied to different areas since they have a great number of crystalline structures $(\alpha, \beta, \gamma, \delta$, etc.) and excellent chemical characteristics. Li batteries which are one of the important applications have been widely studied [3-9]. In addition, $\mathrm{MnO}_{2}$ has been used for catalysts [10-13], supercapacitors [7, 14-17], and so forth. In recent years, $\mathrm{MnO}_{2}$ has been studied as an adsorbent to remove inorganic as well as organic compounds from aqueous solution $[8,18-22]$. However, adsorptive properties of $\alpha-\mathrm{MnO}_{2}$ nanomaterial as well as comparative adsorption of $\mathrm{Pb}(\mathrm{II})$ and $\mathrm{Zn}$ (II) onto this material are seldom reported.

In this study, $\alpha-\mathrm{MnO}_{2}$ was synthesized from heating precursor $\gamma-\mathrm{MnO}_{2}$ and used as an adsorbent to remove $\mathrm{Pb}$ (II) and $\mathrm{Zn}$ (II) from an aqueous solution in an optimal condition. Comparative adsorption of two ions on $\alpha-\mathrm{MnO}_{2}$ was also investigated using three isotherm models: Langmuir, Freundlich, and Sips. The uptake kinetics were analyzed using 
pseudo-first-order and pseudo-second-order models. In addition, intraparticle diffusion kinetics were also studied to ascertain the mechanism of the uptake.

\section{Materials and Methods}

2.1. Preparation of $\alpha-\mathrm{MnO}_{2}$ from $\gamma-\mathrm{MnO}_{2} \cdot \gamma-\mathrm{MnO}_{2}$ which was successfully synthesized by Le and Van Phuc [2] from ethanol and potassium permanganate was heated at $600^{\circ} \mathrm{C}$. The product after being investigated by XRD, SEM, and BET was used as an absorbent to remove lead and iron ions from the aqueous solution.

2.2. Adsorbent. Lead(II) and iron(II) ions were used as adsorbates. $1000 \mathrm{mg} / \mathrm{L}$ standard stock solution of each metal ion was prepared by dissolving $\mathrm{Pb}\left(\mathrm{NO}_{3}\right)_{2}$ and $\mathrm{Fe}\left(\mathrm{NO}_{3}\right)_{3}$ in distilled water.

2.3. Instruments. X-ray diffractometer D5000 made in Germany by Siemens with $\mathrm{X}$-ray radiation $\mathrm{CuK} \alpha, \lambda=1,54056 \AA$, was used to examine the phase of the crystalline structure.

The morphology of the material was investigated by Ultra High Resolution Scanning Electron Microscopy S-4800, a transmission electron microscope.

Atomic Absorption Spectrophotometer (Atomic Absorption Spectrometer AA-7000 made in Japan by Shimadzu) was used to determine the BET surface area and pore site.

The $\mathrm{pH}$ measurements were done with a $\mathrm{pH}$ meter (Martini Instruments Mi-150, Romania); the $\mathrm{pH}$ meter was standardized using Hanna Instruments buffer solutions with $\mathrm{pH}$ values of $4.01 \pm 0.01,7.01 \pm 0.01$, and $10.01 \pm 0.01$.

A temperature-controlled shaker (Model IKA R5) was used for equilibrium studies.

\subsection{Diagram for These Studies. See Figure 1.}

2.5. Adsorption Study. $50 \mathrm{~mL}$ solution of heavy metal $\left(\mathrm{Pb}^{2+}\right.$ and $\mathrm{Zn}^{2+}$ ) ions was placed into a $100 \mathrm{~mL}$ conical flask containing $0.1 \mathrm{~g} \alpha-\mathrm{MnO}_{2}$. During the uptake, influence of $\mathrm{pH}$ of the initial solution was adjusted within 2-5 range using $\mathrm{HNO}_{3}$ $0.1 \mathrm{M}$ or $\mathrm{NaOH} 0.1 \mathrm{M}$ solutions. Adsorption studies were also conducted in batch experiments with various adsorption times (20-240 minutes) and concentrations of metal ion (100-500 mg/L). Concentrations of heavy metal ions in the filtrate before and after uptake were determined using AAS.

Adsorption capacity was calculated by using the mass balance equation for the adsorption [1]:

$$
q=\frac{\left(C_{0}-C_{e}\right) \cdot V}{m} .
$$

And the adsorption efficiency (\%) was calculated from the formula

$$
\% \text { Removal }=\frac{\left(C_{0}-C_{e}\right) \cdot 100 \%}{C_{0}},
$$

where $q$ is the adsorption capacity $(\mathrm{mg} / \mathrm{g}$ ) at equilibrium, $C_{0}$ and $C_{e}$ are the initial and the equilibrium concentrations $(\mathrm{mg} / \mathrm{L})$, respectively, $V$ is the volume $(\mathrm{L})$ of the solution, and $m$ is the mass $(\mathrm{g})$ of the adsorbent used.

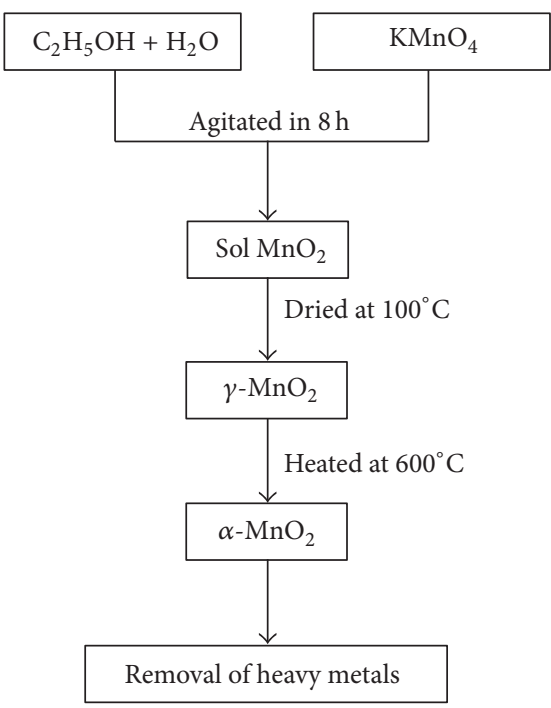

Figure 1

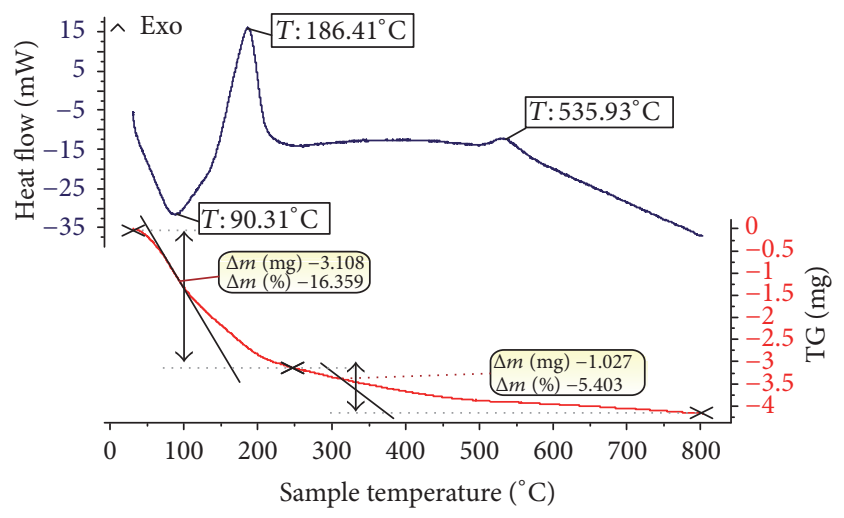

FIgURE 2: TG-DTA analysis.

\section{Results and Discussion}

\subsection{Characterization of $\alpha-\mathrm{MnO}_{2}$ Nanostructures}

3.1.1. Thermal Analysis Result. Thermal analysis (Figure 2) showed that there were two specific peaks corresponding to the decrease in volume of a product. From $100^{\circ} \mathrm{C}$ to $300^{\circ} \mathrm{C}$, the endothermic process occurred which combined with a significant reduction of volume (approximately 16.40\%) showed chemical dehydration as well as melting of material at $186.41^{\circ} \mathrm{C}$. From $300^{\circ} \mathrm{C}$ to $800^{\circ} \mathrm{C}$, there was a slight decrease in volume of about $5.40 \%$ which was the continued melting. In addition, there was an endothermic peak at $535.93^{\circ} \mathrm{C}$ corresponding to allotropic transformation. It was predicted that $\alpha-\mathrm{MnO}_{2}$ crystalline structure can be formed at above $536^{\circ} \mathrm{C}$.

3.1.2. X-Ray Analysis Results. $\mathrm{XRD}$ analysis results showed that $\alpha-\mathrm{MnO}_{2}$ crystalline structure was not formed at $400^{\circ} \mathrm{C}$ (Figure 3). At higher temperatures, $600^{\circ} \mathrm{C}$ and $800^{\circ} \mathrm{C}, \alpha$ $\mathrm{MnO}_{2}$ crystalline structure was completely formed with some specific peaks at $2 \theta=28.58,37.48,49.78,59.98$, and 68.98 corresponding to the Miller indices (3 10$)$, (2 11 1), (4 1 1 1), (5 21 ), 


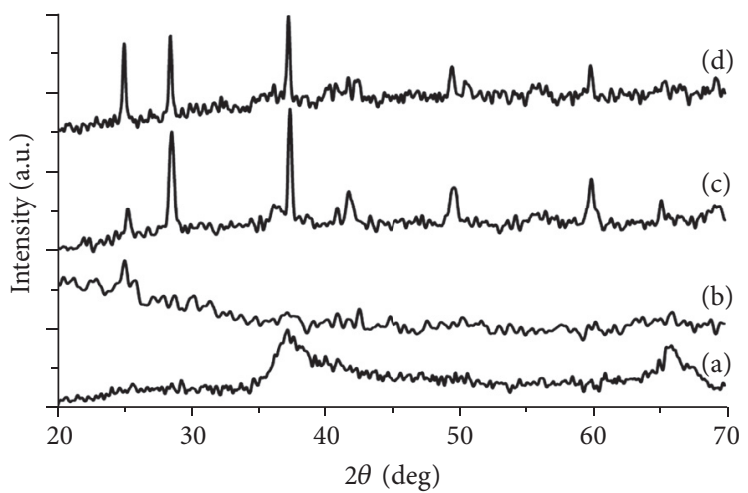

FIgURE 3: XRD image of $\mathrm{MnO}_{2}$ at different temperatures: gamma- $\mathrm{MnO}_{2}(\mathrm{a}) ; t=400^{\circ} \mathrm{C}(\mathrm{b}) ; t=600^{\circ} \mathrm{C}(\mathrm{c})$; and $t=800^{\circ} \mathrm{C}(\mathrm{d})$.

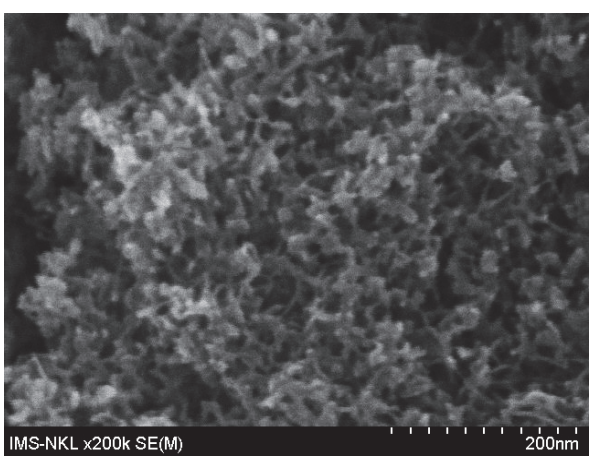

(a)

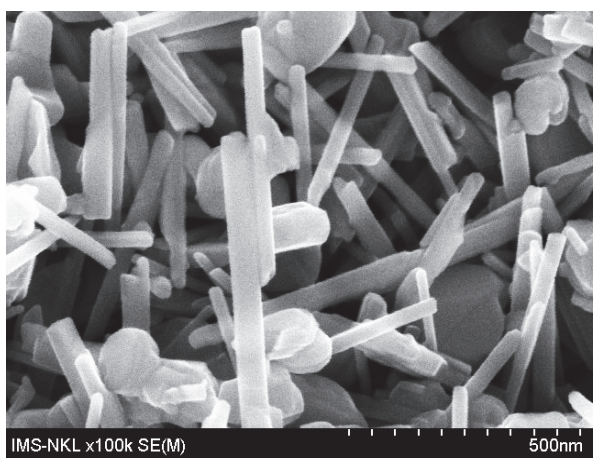

(c)

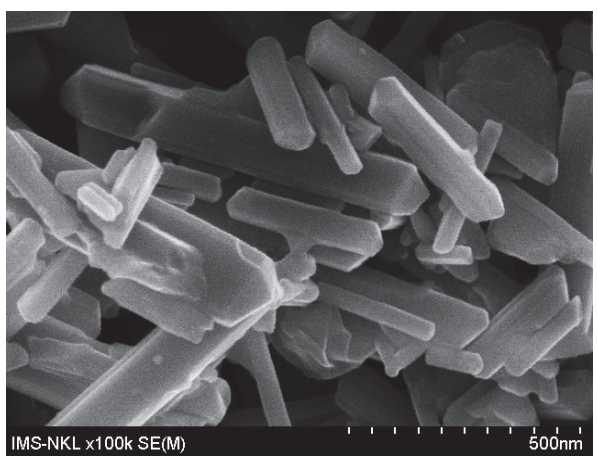

(e)

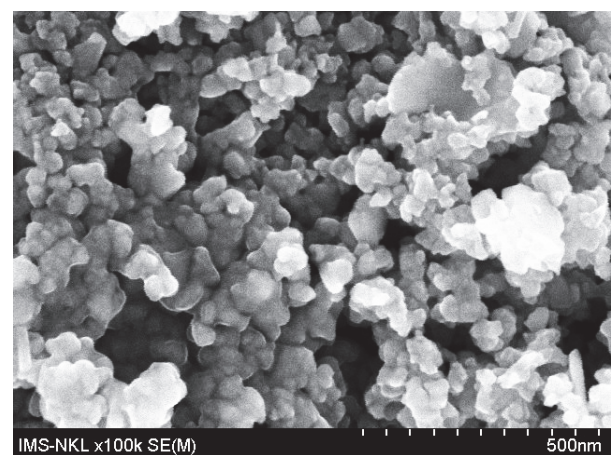

(b)

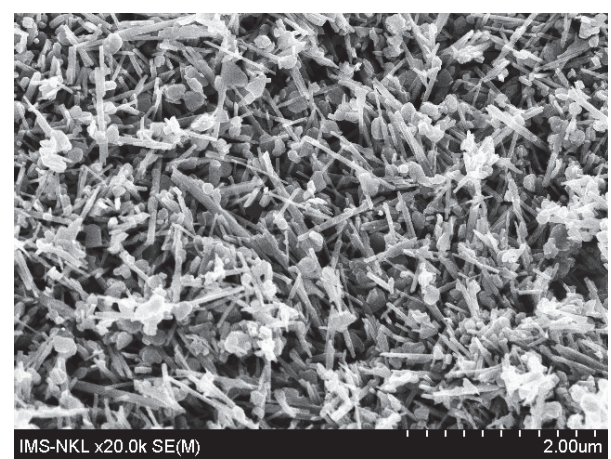

(d)

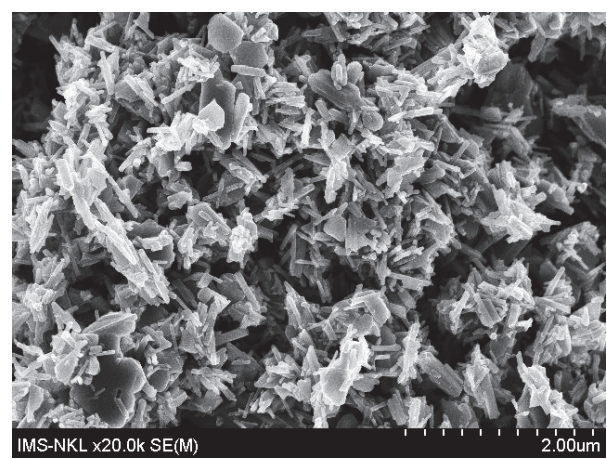

(f)

Figure 4: SEM images of material at $100^{\circ} \mathrm{C}(\mathrm{a}), 400^{\circ}$ (b), $600^{\circ} \mathrm{C}((\mathrm{c}),(\mathrm{d}))$, and $800^{\circ} \mathrm{C}((\mathrm{e}),(\mathrm{f}))$. 
TABLE 1: BET and BJH analysis results of $\gamma-\mathrm{MnO}_{2}$ and $\alpha-\mathrm{MnO}_{2}$.

\begin{tabular}{lccc}
\hline Material & BET surface area & BJH adsorption pore size & BJH desorption pore size \\
\hline$\gamma-\mathrm{MnO}_{2}$ & $65.00 \mathrm{~m}^{2} \cdot \mathrm{g}^{-1}$ & $417.83 \AA$ & $340.23 \AA$ \\
$\alpha-\mathrm{MnO}_{2}$ & $9.37 \mathrm{~m}^{2} \cdot \mathrm{g}^{-1}$ & $162.95 \AA$ & $734.37 \AA$ \\
\hline
\end{tabular}

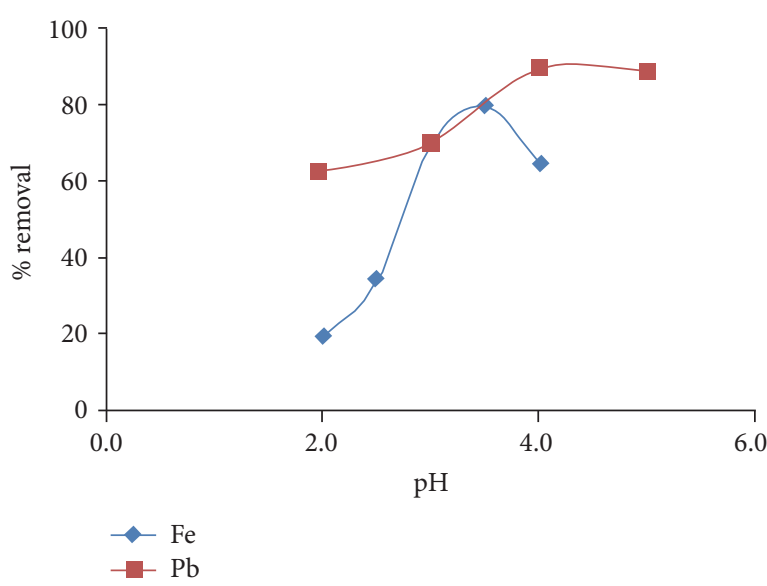

(a)

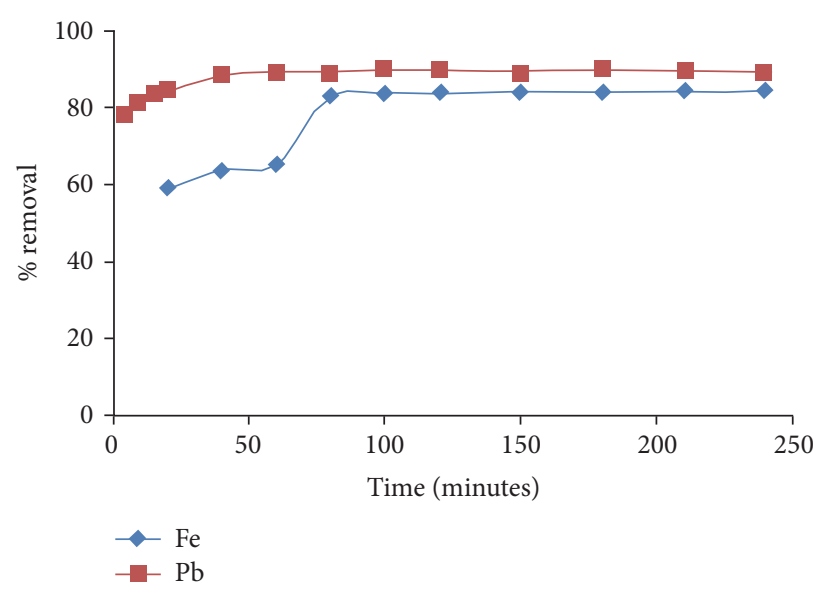

(b)

FIGURE 5: Influence of $\mathrm{pH}$ (a) and contact time (b) on adsorption of $\mathrm{Pb}$ (II) and $\mathrm{Fe}(\mathrm{III})$ at room temperature with $240 \mathrm{rpm}$ of shaking speed.

and (5 4 1), respectively (ref. code: 01-072-1982). These results corresponded with prognostication from thermal analysis.

3.1.3. Scanning Electron Microscopy Analysis Results. Figure 4 showed that although $\gamma-\mathrm{MnO}_{2}$ particles were flocculated at $400^{\circ} \mathrm{C}$, the morphology of material was not changed. It can be concluded that $\alpha-\mathrm{MnO}_{2}$ nanostructures were not formed. At $600^{\circ} \mathrm{C}$ and $800^{\circ} \mathrm{C}$, the morphology of the material was changed from nanospheres to nanorods which coincided with $\alpha-\mathrm{MnO}_{2}$ crystalline nanostructure corresponding to $\mathrm{XRD}$ results. However, these nanorods were broken and smashed at $800^{\circ} \mathrm{C}$.

3.1.4. BET Surface Area and BJH Analysis. The BET surface area as well as $\mathrm{BJH}$ adsorption-desorption pore size of $\alpha-\mathrm{MnO}_{2}$ and $\gamma-\mathrm{MnO}_{2}$ was provided in Table 1 . Whereas precursor $\gamma-\mathrm{MnO}_{2}$ had a BET surface area of about $65 \mathrm{~m}^{2} \cdot \mathrm{g}^{-1}$, the synthesized $\alpha-\mathrm{MnO}_{2}$ had smaller surface, approximately $9.4 \mathrm{~m}^{2} \cdot \mathrm{g}^{-1}$. This can be explained by the fact that $\gamma-\mathrm{MnO}_{2}$ was composed of nanospheres, had a porous surface, and was small in size at room temperature. When heating $\gamma-\mathrm{MnO}_{2}$ to form $\alpha-\mathrm{MnO}_{2}$ at $600^{\circ} \mathrm{C}$, nanospheres were melted, flocculated, and showed an increase in size. As a result, $\alpha-\mathrm{MnO}_{2}$ had a smaller surface area than precursor $\gamma-\mathrm{MnO}_{2}$. Both $\gamma-\mathrm{MnO}_{2}$ and $\alpha-\mathrm{MnO}_{2}$ had $\mathrm{BJH}$ adsorption average pore width from $20 \AA$ to $50 \AA$ which were mesopores materials. However, with the fact that $\mathrm{BJH}$ adsorption pore size of $\gamma-\mathrm{MnO}_{2}$ is smaller than that of $\alpha-\mathrm{MnO}_{2}$, it was revealed that adsorptive properties of $\gamma-\mathrm{MnO}_{2}$ were better than those of $\alpha-\mathrm{MnO}_{2}$.

\subsection{Adsorption Studies}

3.2.1. Effective Factors. $\mathrm{pH}$ plays an important role in absorbing $\mathrm{Pb}(\mathrm{II})$ and $\mathrm{Fe}(\mathrm{III})$ ions onto $\alpha-\mathrm{MnO}_{2}$ material surface.
At higher $\mathrm{pH}$ value, hydroxo ion $\mathrm{MOH}^{n+}$ or/and insoluble hydroxide $\mathrm{M}(\mathrm{OH})_{n}$ was easily formed which inhibits the adsorption of these ions. In contrast, at low $\mathrm{pH}$ value, adsorption sites may be decreased because part of the $\mathrm{MnO}_{2}$ nanomolecules can be dissolved in an acid solution as in the following reaction:

$$
\mathrm{MnO}_{2}+4 \mathrm{H}^{+}+\mathrm{e}^{-} \longrightarrow \mathrm{Mn}^{2+}+2 \mathrm{H}_{2} \mathrm{O}
$$

As a result, adsorption reached a maximum at $\mathrm{pH}=4.0$ for $\mathrm{Pb}(\mathrm{II})$ and $\mathrm{pH}=3.5$ for $\mathrm{Fe}(\mathrm{III})$ (Figure 5(a)).

Adsorption time is one of the important factors which helps us to predict kinetics as well as the mechanism of the uptake of heavy metals on material surface. The influence of contact time on the adsorption process of $\mathrm{Pb}$ (II) and $\mathrm{Fe}$ (III) onto $\alpha-\mathrm{MnO}_{2}$ was shown in Figure 5(b). As a result, the adsorption equilibrium was obtained after 60 minutes for $\mathrm{Pb}(\mathrm{II})$ and 80 minutes for $\mathrm{Fe}(\mathrm{III})$.

3.2.2. Isotherm Equation Studies. To understand the nature of the adsorption of $\mathrm{Pb}$ (II) and $\mathrm{Fe}$ (III) on material surface, some isotherm equations, such as Langmuir, Freundlich, and Sips, were investigated. While Langmuir model can help us to calculate the maximum adsorption capacity on a monolayer, Freundlich model shows the interaction between the absorbent and a multilayer. Plots of these nonlinear equations and equilibrium isotherm parameters were shown in Figure 6 and Table 2. Results showed that the maximum adsorption capacities calculated from Langmuir model were $124.87 \mathrm{mg} / \mathrm{g}$ for $\mathrm{Pb}$ (II) and $30.83 \mathrm{mg} / \mathrm{g}$ for Fe(III). This can be explained by the fact that lead ion is more satisfied with adsorption pore size because it has ion radius larger than iron. In addition, 

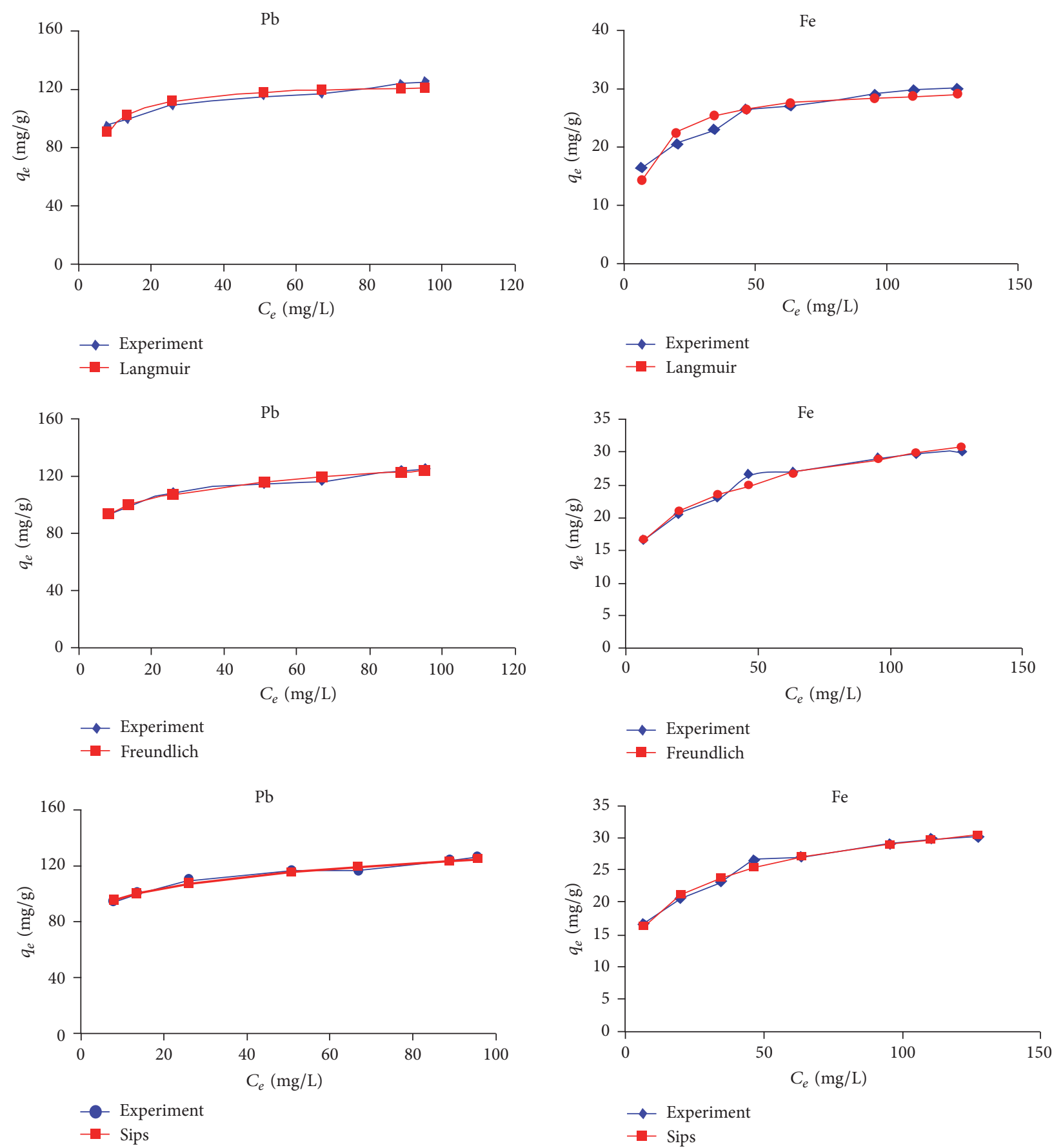

Figure 6: Plots of adsorption isotherm models: Langmuir, Freundlich, and Sips models.

the separation factor, $S_{F}$, which is a dimensionless constant equilibrium parameter, was given by

$$
S_{F}=\frac{1}{1+K_{L} \cdot C_{0}} \text {. }
$$

Based on the $S_{F}$ value, it can be revealed that the smaller the value of $S_{F}$ is, the more favorable the adsorption is. The calculated $S_{F}$ values which were smaller than 1 and higher than 0 in both the lowest and the highest concentrations showed that $\alpha-\mathrm{MnO}_{2}$ was an appropriate adsorbent for
$\mathrm{Fe}(\mathrm{III})$ and $\mathrm{Pb}(\mathrm{II})$. However, $S_{F}$ value of $\mathrm{Pb}(\mathrm{II})>\mathrm{Fe}(\mathrm{III})$ indicated that $\mathrm{Fe}(\mathrm{III})$ will compete for binding sites faster than $\mathrm{Pb}(\mathrm{II})$ in a mixed metal ions system.

Moreover, the $1 / n$ values calculated from Freundlich model for $\mathrm{Fe}(\mathrm{III})$ higher than $\mathrm{Pb}$ (II) indicated that the interaction between $\alpha-\mathrm{MnO}_{2}$ and $\mathrm{Fe}(\mathrm{III})$ is more favorable than $\alpha-\mathrm{MnO}_{2}$ and $\mathrm{Pb}(\mathrm{II})$.

However, the material surface shows heterogeneity. Hence, the uptake of heavy metal ions onto $\mathrm{MnO}_{2}$ can occur on different mechanisms. Sips model, which is Langmuir and 
TABLE 2: Equilibrium isotherm parameters.

\begin{tabular}{|c|c|c|c|c|}
\hline \multirow{2}{*}{ Isotherm } & \multirow{2}{*}{ Nonlinear forms } & \multicolumn{3}{|c|}{ Isotherm parameters } \\
\hline & & & $\mathrm{Pb}(\mathrm{II})$ & $\mathrm{Fe}(\mathrm{III})$ \\
\hline \multirow{7}{*}{ Langmuir } & \multirow{7}{*}{$q_{e}=\frac{q_{m} \cdot K_{L} \cdot C_{e}}{1+K_{L} \cdot C_{e}}$} & $K_{L}$ & 0.3340 & 0.135 \\
\hline & & $q_{m}(\mathrm{mg} / \mathrm{g})$ & 124.9 & 30.83 \\
\hline & & RMSE & 3.529 & 1.504 \\
\hline & & $R^{2}$ & 0.9109 & 0.9042 \\
\hline & & $\chi^{2}$ & 0.6618 & 0.7603 \\
\hline & & $S_{F}$ (at the lowest $C_{0}$ ) & 0.0291 & 0.0689 \\
\hline & & $S_{F}$ (at the highest $C_{0}$ ) & $5.95 \cdot 10^{-3}$ & 0.0146 \\
\hline \multirow{5}{*}{ Freundlich } & \multirow{5}{*}{$q_{e}=K_{F} \cdot C_{e}^{1 / n}$} & $1 / n$ & 0.1115 & 0.2033 \\
\hline & & $K_{F}$ & 74.76 & 11.52 \\
\hline & & RMSE & 1.493 & 0.695 \\
\hline & & $R^{2}$ & 0.9840 & 0.9795 \\
\hline & & $x^{2}$ & 0.1148 & 0.1296 \\
\hline \multirow{6}{*}{ Sips } & \multirow{6}{*}{$q_{e}=\frac{K_{S} \cdot C_{e}^{\beta_{S}}}{1+\alpha_{S} \cdot C_{e}^{\beta_{S}}}$} & $K_{S}$ & 6.75 & 11.84 \\
\hline & & $\alpha_{S}$ & -0.9142 & 0.1986 \\
\hline & & $\beta_{S}$ & 0.0070 & 0.3442 \\
\hline & & RMSE & 1.4689 & 0.6272 \\
\hline & & $R^{2}$ & 0.9846 & 0.9833 \\
\hline & & $\chi^{2}$ & 0.1133 & 0.1122 \\
\hline
\end{tabular}

$q_{e}$ : adsorption capacity at equilibrium (mg/g); $q_{m}$ : maximum adsorption capacity $(\mathrm{mg} / \mathrm{g}) ; C_{e}$ : equilibrium concentration $(\mathrm{mg} / \mathrm{L}) ; K_{L}:$ Langmuir constant; $K_{F}$ : Freundlich constant; $n$ : adsorption intensity; $K_{S}$ : Sips constant; $\alpha_{S}$ : Sips isotherm model constant (L/mg); $\beta_{S}$ : Sips isotherm model exponent; $R^{2}$ : correlation coefficient; RMSE: root mean square error; $\chi^{2}$ : nonlinear chi-square test.

Freundlich models combined, generally described exactly the nature of adsorption. Sips isotherm equation was given by formula [1]

$$
q_{e}=\frac{K_{S} \cdot C_{e}^{\beta_{S}}}{1+\alpha_{S} \cdot C_{e}^{\beta_{S}}},
$$

where $\alpha_{S}$ is Sips isotherm model constant ( $\left.\mathrm{L} / \mathrm{mg}\right) ; \beta_{S}$ is Sips isotherm model exponent; $K_{S}$ is Sips constant; $C_{e}(\mathrm{mg} / \mathrm{L})$ is the equilibrium concentration; and $q_{e}(\mathrm{mg} / \mathrm{g})$ is adsorption capacity. Sips equation is a three-parameter model, and thus it can be solved by Solver Add-In in Microsoft Excel.

In comparison with the correlation coefficients $\left(R^{2}\right)$, the root mean square error (RMSE), and the nonlinear chi-square test $\left(\chi^{2}\right)$ values of the three models, it was clear that the adsorption of $\mathrm{Pb}$ (II) and $\mathrm{Fe}$ (III) onto $\alpha-\mathrm{MnO}_{2}$ followed Sips model due to the highest $R^{2}$ value as well as the lowest RMSE and $\chi^{2}$ ones.

3.2.3. Kinetic Studies. Pseudo-first-order and pseudosecond-order models are often used to describe the uptake of heavy metal ions onto material surface for adsorption time. Kinetic parameters give essential information for designing and modeling the adsorption processes. However, the two modes cannot determine clearly the nature of the adsorption of $\mathrm{Pb}$ (II) and $\mathrm{Fe}(\mathrm{III})$ onto $\alpha-\mathrm{MnO}_{2}$ nanomaterial. Therefore, intraparticle diffusion model which was developed by Weber and Morris was applied for ascertaining a mechanism of the uptake of $\mathrm{Pb}(\mathrm{II})$ and $\mathrm{Fe}(\mathrm{III})$ onto $\alpha-\mathrm{MnO}_{2}$. Plots of these kinetic models were shown in Figure 7 and kinetic parameters were given in Table 3.

Results showed that the theoretical $q_{e}$ values which were calculated from pseudo-second-order kinetic models were more accordant with the experimental values, $q_{e(\exp )}$, than pseudo-first-order kinetic ones. In addition, correlation coefficients in these pseudo-second-order kinetic models for both $\mathrm{Pb}$ (II) and $\mathrm{Fe}$ (III) were higher than 0.9950. It was revealed that pseudo-second-order models were satisfied with describing kinetics of the uptake of $\mathrm{Pb}$ (II) and $\mathrm{Fe}$ (III) on $\alpha-\mathrm{MnO}_{2}$.

Furthermore, intraparticle diffusion models showed that the uptake of $\mathrm{Pb}$ (II) followed two stages: firstly, $\mathrm{Pb}$ (II) ions were quickly adsorbed on $\alpha-\mathrm{MnO}_{2}$ surface; secondly, there was gradual diffusion of absorbents from surface sites into the inner pores. And it was observed that there are three stages in the sorption of Fe(III) ion on the material surface. In the first one, $\mathrm{Fe}$ (III) ion was rapidly transferred from the solution to $\alpha-\mathrm{MnO}_{2}$ surface. In the next one, intraparticle diffusion which is the controlling factor gradually occurred. Lastly, the adsorption equilibrium was obtained to correspond with the saturation of absorbent sites. The intraparticle diffusion constants for all these stages were given in Table 3.

\section{Conclusion}

In this report, $\alpha-\mathrm{MnO}_{2}$ nanostructure synthesized from a precursor $\gamma-\mathrm{MnO}_{2}$ was used as an adsorbent to remove $\mathrm{Pb}$ (II) and $\mathrm{Fe}(\mathrm{III})$ from an aqueous solution at an optimal 


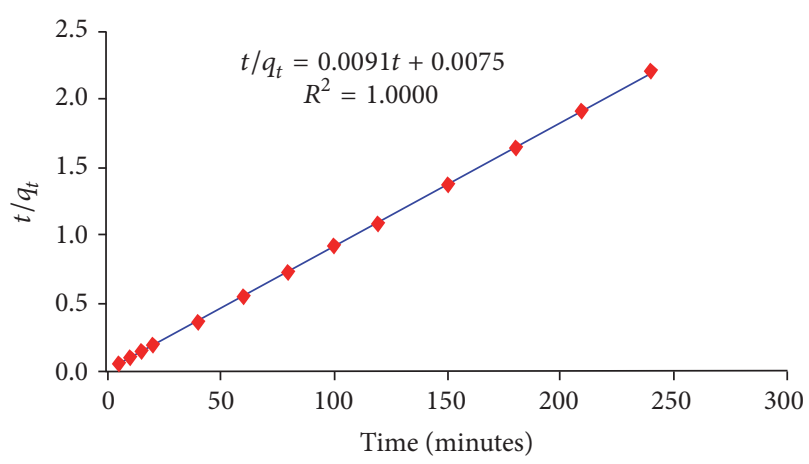

(a)

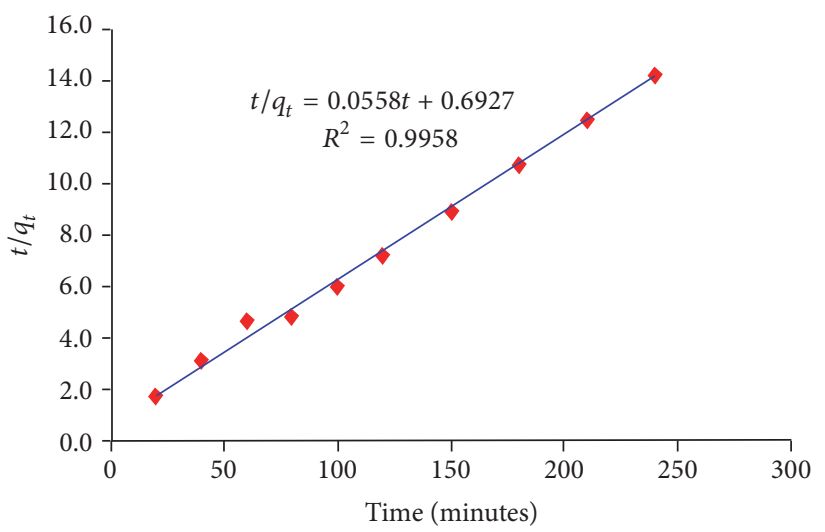

(c)

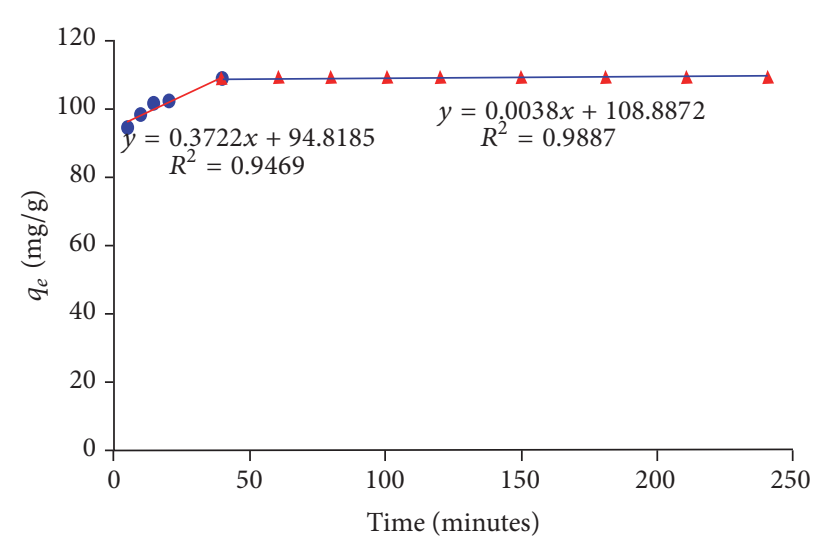

- Stage 1

$\Delta$ Stage 2

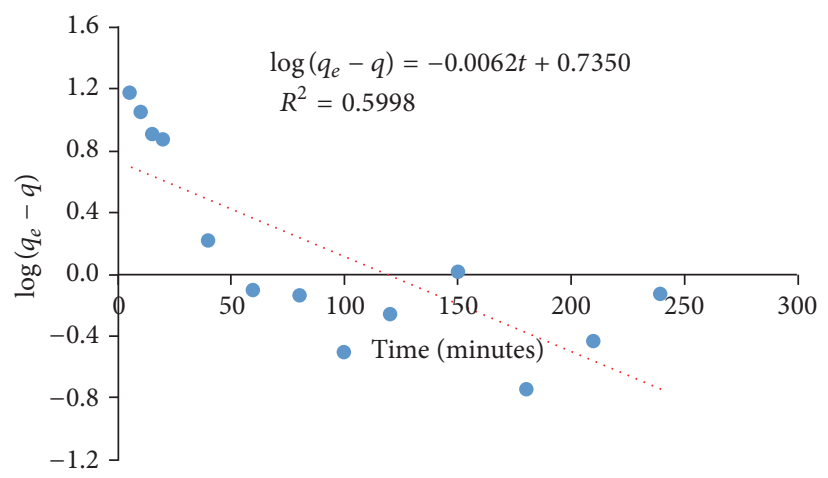

(b)

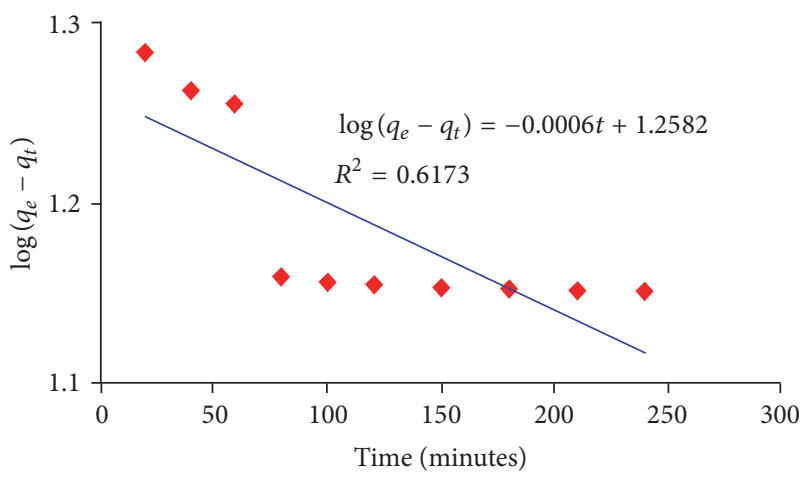

(d)

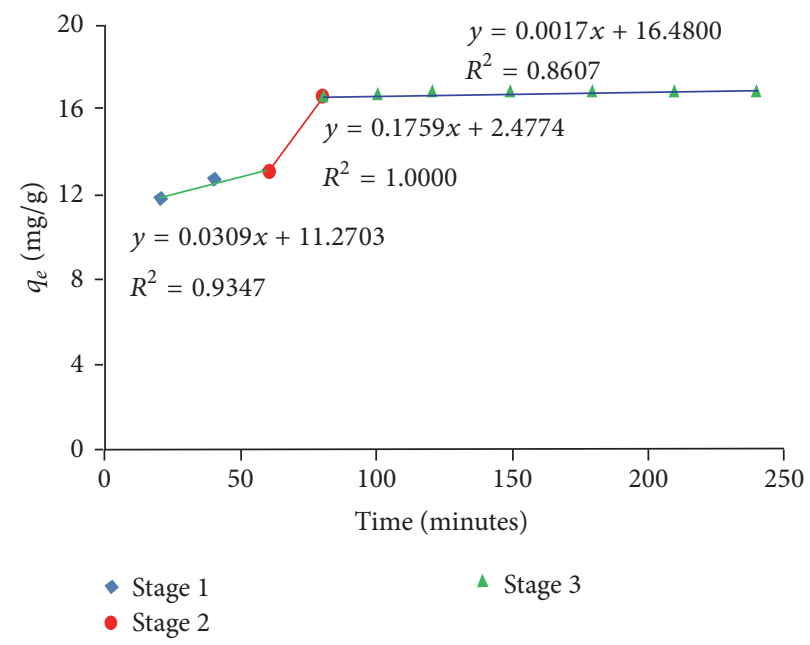

(f)

FIGURE 7: Pseudo-first-order kinetic plots for the adsorption of $\mathrm{Pb}$ (II) (a) and Fe(III) (c). Pseudo-second-order kinetic plots for the adsorption of $\mathrm{Pb}(\mathrm{II})$ (b) and $\mathrm{Fe}(\mathrm{III})$ (d). Intraparticle diffusion kinetic plots for the adsorption of $\mathrm{Pb}$ (II) (e) and $\mathrm{Fe}(\mathrm{III})$ (f).

condition. Results showed that the maximum capacities were $124.87 \mathrm{mg} / \mathrm{g}$ for $\mathrm{Pb}$ (II) and $30.83 \mathrm{mg} / \mathrm{g}$ for $\mathrm{Fe}(\mathrm{III})$ at $\mathrm{pH}=4.0$ for $\mathrm{Pb}(\mathrm{II})$ and $\mathrm{pH}=3.5$ for $\mathrm{Fe}(\mathrm{III})$. Experiment data which was analyzed using three isotherm models, that is, Langmuir, Freundlich, and Sips, indicated that Sips model was fitted better than the other two. Kinetics studies showed that both $\mathrm{Pb}$ (II) and $\mathrm{Fe}$ (III) corresponded with pseudo-second-order model with corelation coefficient constants $\left(R^{2}\right)$ higher than
0.9950. Intraparticle diffusion kinetics confirmed that the uptake of $\mathrm{Pb}$ (II) on $\alpha-\mathrm{MnO}_{2}$ includes two stages while it includes three stages for $\mathrm{Fe}(\mathrm{III})$.

\section{Competing Interests}

The authors declare that there are no competing interests regarding the publication of this paper. 
TABLE 3: Kinetic parameters.

\begin{tabular}{|c|c|c|c|c|}
\hline \multirow{2}{*}{ Kinetic models } & \multirow{2}{*}{ Linear forms } & \multirow[t]{2}{*}{ Kinetic parameters } & \multirow[b]{2}{*}{$\mathrm{Pb}(\mathrm{II})$} & \multirow[b]{2}{*}{$\mathrm{Fe}(\mathrm{III})$} \\
\hline & & & & \\
\hline & & $q_{e(\exp )}(\mathrm{mg} / \mathrm{g})$ & 109.80 & 16.80 \\
\hline \multirow{3}{*}{$\begin{array}{l}\text { Pseudo-first-order model } \\
\frac{d q}{d t}=K_{1}\left(q_{e}-q\right)\end{array}$} & \multirow{3}{*}{$\log \left(q_{e}-q_{t}\right)=\log q_{e}-\frac{K_{1} \cdot t}{2,303}$} & $K_{1}\left(\min ^{-1}\right)$ & 0.01428 & $1.38 \cdot 10^{-3}$ \\
\hline & & $R^{2}$ & 0.5998 & 0.6873 \\
\hline & & $q_{e(\mathrm{cal})}(\mathrm{mg} / \mathrm{g})$ & 5.433 & 18.12 \\
\hline \multirow{3}{*}{$\begin{array}{l}\text { Pseudo-second-order model } \\
\frac{d q}{d t}=K_{2}\left(q_{e}-q\right)^{2}\end{array}$} & \multirow{3}{*}{$\frac{t}{q}=\frac{1}{K_{2} q_{e}^{2}}+\left(\frac{1}{q_{e}}\right) \cdot t$} & $K_{2}\left(\mathrm{~g} \cdot \mathrm{mg}^{-1} \cdot \mathrm{min}^{-1}\right)$ & 0.01108 & $4.5 \cdot 10^{-3}$ \\
\hline & & $R^{2}$ & 1.000 & 0.9958 \\
\hline & & $q_{e(\mathrm{cal})}(\mathrm{mg} / \mathrm{g})$ & 109.89 & 17.92 \\
\hline \multirow{3}{*}{ Intraparticle diffusion model } & \multirow{3}{*}{$q_{t}=K_{d} t^{1 / 2}+C$} & $K_{d 1}$ & 0.3722 & 0.0309 \\
\hline & & $K_{d 2}$ & 0.0038 & 0.1759 \\
\hline & & $K_{d 3}$ & & 0.0017 \\
\hline
\end{tabular}

\section{References}

[1] K. Y. Foo and B. H. Hameed, "Insights into the modeling of adsorption isotherm systems," Chemical Engineering Journal, vol. 156, no. 1, pp. 2-10, 2010.

[2] N. C. Le and D. Van Phuc, "Sorption of lead (II), cobalt (II) and copper (II) ions from aqueous solutions by $\gamma-\mathrm{MnO}_{2}$ nanostructure," Advances in Natural Sciences: Nanoscience and Nanotechnology, vol. 6, no. 2, Article ID 025014, 2015.

[3] M. M. Thackeray and A. De Kock, "Synthesis of $\gamma-\mathrm{MnO}_{2}$ from $\mathrm{LiMn}_{2} \mathrm{O}_{4}$ for $\mathrm{Li} / \mathrm{MnO}_{2}$ battery applications," Journal of Solid State Chemistry, vol. 74, no. 2, pp. 414-418, 1988.

[4] S. Sarciaux, A. Le Gal La Salle, A. Verbaere, Y. Piffard, and D. Guyomard, " $\gamma-\mathrm{MnO}_{2}$ for Li batteries Part I. $\gamma-\mathrm{MnO}_{2}$ : relationships between synthesis conditions, material characteristics and performances in lithium batteries," Journal of Power Sources, vol. 81-82, pp. 656-660, 1999.

[5] K. S. Abou-El-Sherbini, "Structure investigation and electrochemical behavior of $\gamma-\mathrm{MnO}_{2}$ synthesized from threedimensional framework and layered structures," Journal of Solid State Chemistry, vol. 166, no. 2, pp. 375-381, 2002.

[6] L. I. Hill, A. Verbaere, and D. Guyomard, " $\mathrm{MnO}_{2}(\alpha-, \beta-$, $\gamma$-) compounds prepared by hydrothermal-electrochemical synthesis: characterization, morphology, and lithium insertion behavior," Journal of Power Sources, vol. 119-121, pp. 226-231, 2003.

[7] Y. Li, H. Xie, J. Wang, and L. Chen, "Preparation and electrochemical performances of $\alpha-\mathrm{MnO}_{2}$ nanorod for supercapacitor," Materials Letters, vol. 65, no. 2, pp. 403-405, 2011.

[8] J. Li, B. Xi, Y. Zhu, Q. Li, Y. Yan, and Y. Qian, "A precursor route to synthesize mesoporous $\gamma-\mathrm{MnO}_{2}$ microcrystals and their applications in lithium battery and water treatment," Journal of Alloys and Compounds, vol. 509, no. 39, pp. 9542-9548, 2011.

[9] M. R. Bailey and S. W. Donne, "Structural effects on the cyclability of the alkaline $\gamma-\mathrm{MnO}_{2}$ electrode," Electrochimica Acta, vol. 56, no. 14, pp. 5037-5045, 2011.

[10] L. Jin, C.-H. Chen, V. M. B. Crisostomo, L. Xu, Y.-C. Son, and S. L. Suib, " $\gamma-\mathrm{MnO}_{2}$ octahedral molecular sieve: preparation, characterization, and catalytic activity in the atmospheric oxidation of toluene," Applied Catalysis A: General, vol. 355, no. 1-2, pp. 169-175, 2009.
[11] T. Lin, L. Yu, M. Sun, G. Cheng, B. Lan, and Z. Fu, "Mesoporous $\alpha-\mathrm{MnO}_{2}$ microspheres with high specific surface area: controlled synthesis and catalytic activities," Chemical Engineering Journal, vol. 286, pp. 114-121, 2016.

[12] Y. Wu, S. Li, Y. Cao, S. Xing, Z. Ma, and Y. Gao, "Facile synthesis of mesoporous $\alpha-\mathrm{MnO}_{2}$ nanorod with three-dimensional frameworks and its enhanced catalytic activity for VOCs removal," Materials Letters, vol. 97, pp. 1-3, 2013.

[13] X. Fu, J. Feng, H. Wang, and K. M. Ng, "Manganese oxide hollow structures with different phases: synthesis, characterization and catalytic application," Catalysis Communications, vol. 10, no. 14, pp. 1844-1848, 2009.

[14] H. Wei, J. Wang, S. Yang, Y. Zhang, T. Li, and S. Zhao, "Facile hydrothermal synthesis of one-dimensional nanostructured $\alpha$ $\mathrm{MnO}_{2}$ for supercapacitors," Physica E: Low-dimensional Systems and Nanostructures, vol. 83, pp. 41-46, 2016.

[15] N. Boukmouche, N. Azzouz, L. Bouchama, A. Lise Daltin, J. Paul Chopart, and Y. Bouznit, "Supercapacitance of $\mathrm{MnO}_{2}$ films prepared by pneumatic spray method," Materials Science in Semiconductor Processing, vol. 27, no. 1, pp. 233-239, 2014.

[16] M. Pang, G. Long, S. Jiang et al., "One pot low-temperature growth of hierarchical $\delta-\mathrm{MnO}_{2}$ nanosheets on nickel foam for supercapacitor applications," Electrochimica Acta, vol. 161, pp. 297-304, 2015.

[17] Z. Li, Z. Liu, B. Li et al., "Large area synthesis of well-dispersed $\beta-\mathrm{MnO}_{2}$ nanorods and their electrochemical supercapacitive performances," Journal of the Taiwan Institute of Chemical Engineers, vol. 65, pp. 544-551, 2016.

[18] D. Nguyen Thanh, M. Singh, P. Ulbrich, N. Strnadova, and F. Štěpánek, "Perlite incorporating $\gamma-\mathrm{Fe}_{2} \mathrm{O}_{3}$ and $\alpha-\mathrm{MnO}_{2}$ nanomaterials: preparation and evaluation of a new adsorbent for As (V) removal," Separation and Purification Technology, vol. 82, no. 1, pp. 93-101, 2011.

[19] M. Wang, P. Pang, L. K. Koopal, G. Qiu, Y. Wang, and F. Liu, "One-step synthesis of $\delta-\mathrm{MnO}_{2}$ nanoparticles using ascorbic acid and their scavenging properties to $\mathrm{Pb}(\mathrm{II}), \mathrm{Zn}(\mathrm{II})$ and methylene blue," Materials Chemistry and Physics, vol. 148, no. 3, pp. 1149-1156, 2014.

[20] Y. Du, G. Zheng, J. Wang, L. Wang, J. Wu, and H. Dai, " $\mathrm{MnO}_{2}$ nanowires in situ grown on diatomite: highly efficient absorbents for the removal of $\mathrm{Cr}(\mathrm{VI})$ and $\mathrm{As}(\mathrm{V})$," Microporous and Mesoporous Materials, vol. 200, pp. 27-34, 2014.

[21] X. Ge, J. Liu, X. Song et al., "Hierarchical iron containing $\gamma$ $\mathrm{MnO}_{2}$ hollow microspheres: a facile one-step synthesis and 
effective removal of As(III) via oxidation and adsorption," Chemical Engineering Journal, vol. 301, pp. 139-148, 2016.

[22] M. Gheju, I. Balcu, and G. Mosoarca, "Removal of Cr(VI) from aqueous solutions by adsorption on $\mathrm{MnO}_{2}$," Journal of Hazardous Materials, vol. 310, pp. 270-277, 2016. 

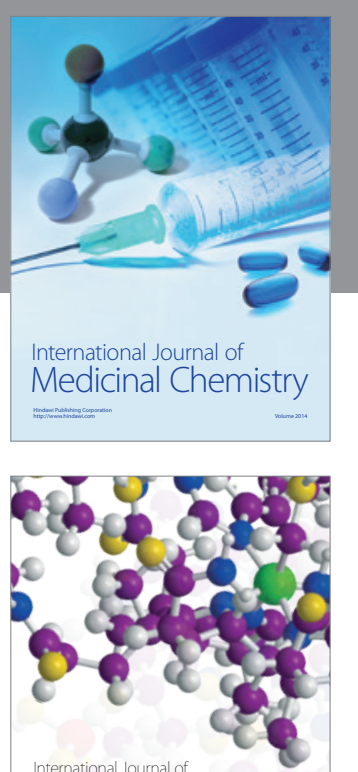

Carbohydrate Chemistry

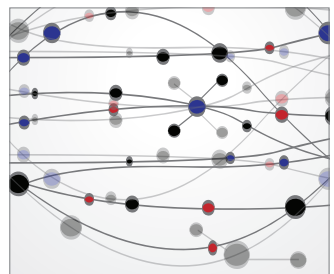

The Scientific World Journal
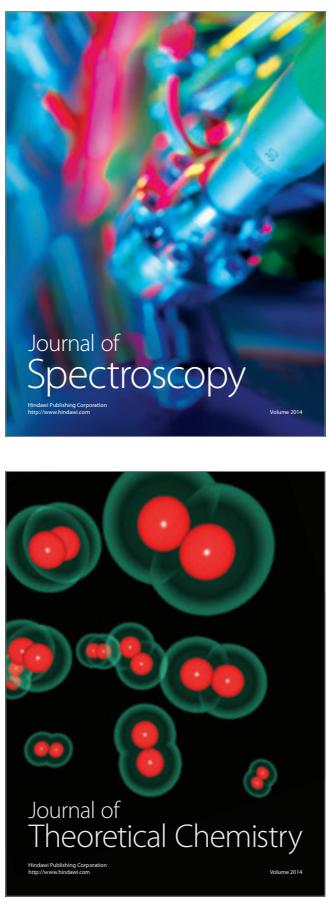
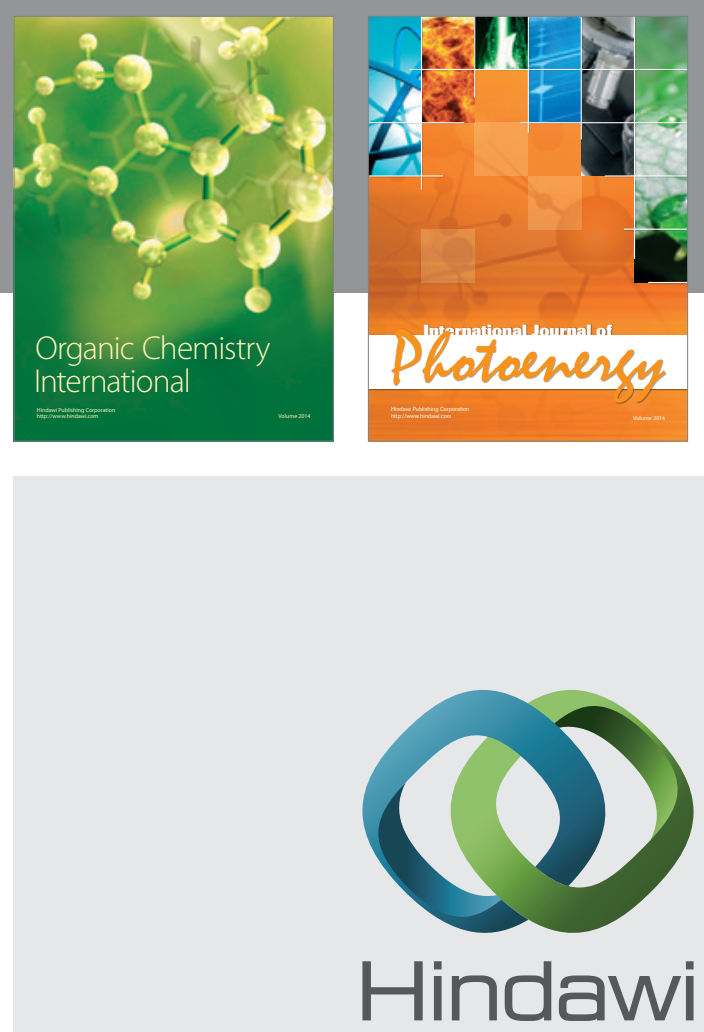

Submit your manuscripts at

http://www.hindawi.com

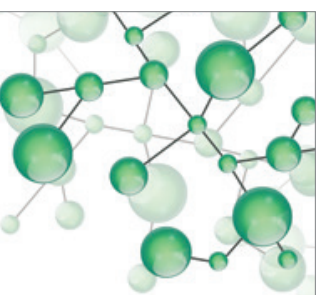

International Journal of

Inorganic Chemistry

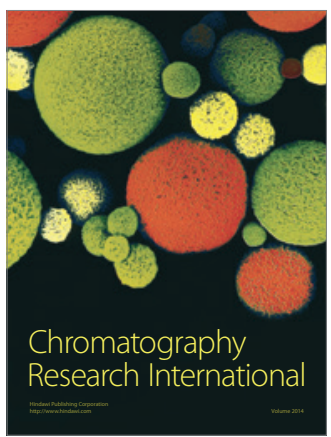

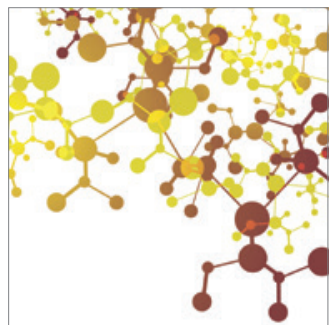

Applied Chemistry
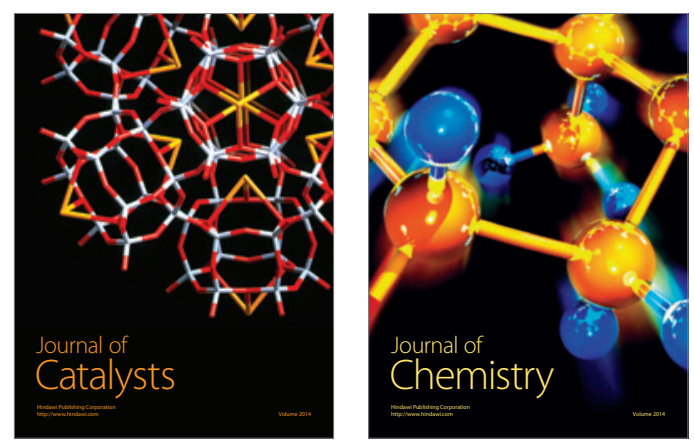
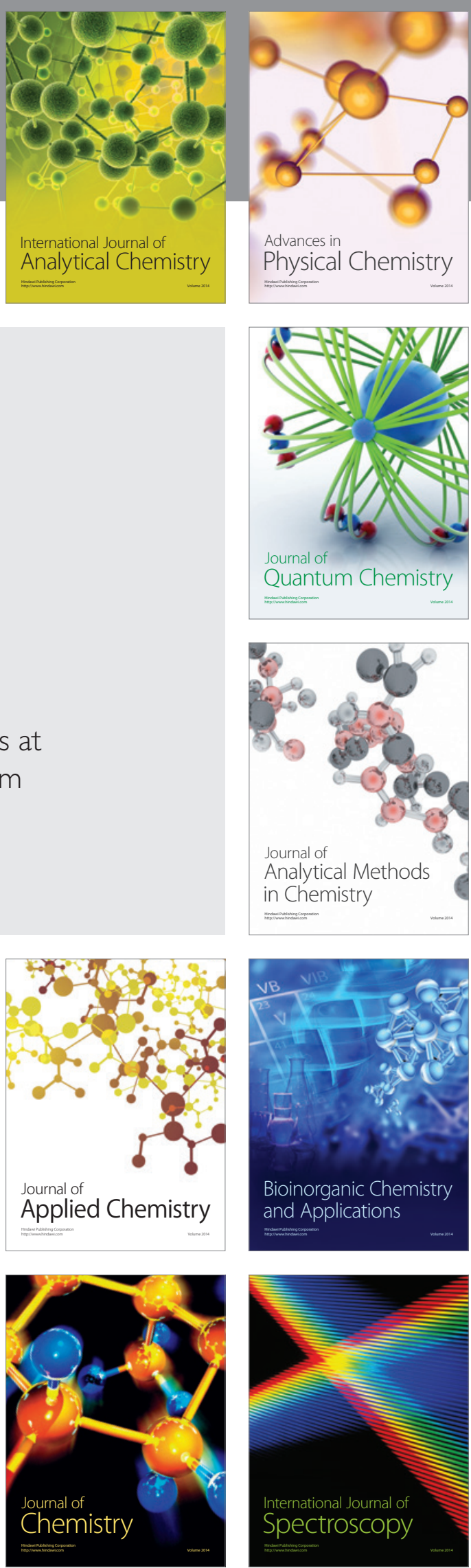